\title{
The power of the dead in Neolithic landscapes: an agricultural-celestial metaphor in the funerary tradition of the Funnel Beaker Culture in the Sandomierz Upland
}

\author{
Stanisław Iwaniszewski \\ Escuela Nacional de Antropología e Historia, Ciudad de México, MX \\ Państwowe Muzeum Archeologiczne, Warszawa, PL \\ siwanisz@yahoo.com
}

\begin{abstract}
FBC earthen long barrows were roughly oriented along the East-West axis, with deviations not exceeding the frame of the solar arc. Also, the Sandomierz Group monuments display this general pattern. The paper brings together archaeoastronomy, landscape archaeology and symbolic archaeology.
\end{abstract}

IZVLEČEK - Dolge zemljene gomile kulture lijakastih čaš so v glavnem orientirane v smeri vzhod-zahod in ne presegajo okvirja solarnega loka. Tudi spomeniki skupine Sandomierz kažejo na podobne vzorce. V članku združujemo spoznanja iz področja arheoastronomije, prostorske arheologije in simbolične arheologije.

KEY WORDS - Funnel Beaker Culture; long barrows; Sandomierz Upland; calendar dates; archaeoastronomy

\section{Introduction}

One of the essential features of the Funnel Beaker Culture (FBC) was the development of long monumental barrows with timber structures. Having elongated, almost triangular or asymmetrical trapezoidal forms with wider 'entrances' or 'facades' and narrower ends, they were often located in abandoned agricultural fields or settlements near wet or boggy areas (Midgley 2008.11-12; Woźny 1996.94-96; Adamczak 2013.184-186). Their elongated shapes seem to evoke the concept of axiality, suggesting they were carefully positioned in the landscape. Archaeoastronomy may elicit the meaning of orienting long barrows in one direction or another. In this paper, I report on an ongoing study of orientations of long barrows in the Sandomierz Upland, in central-southeastern Poland.

Traditionally, the Funnel Beaker Culture area is divided into five broad groups (Midgley 1992.41, Fig. 10; 2008.2-3, Fig. 1.1): western (Holland and adjacent Germany), northern (southern Scandinavia,
Denmark, Holstein, Mecklenburg and Brandenburg), eastern (lower Oder, Silesia, Greater Poland, Kuyavia, Chełmno Land, and Pomerania), southern (middle and upper Elbe, upper Oder) and southern-eastern (Little Poland). The Little Poland group is further subdivided into four smaller regions: Cracow, Sandomierz, Lublin, and Volhynia (Burchard et al. 1991.96; Kruk, Milisauskas 1999.109-110, 312313), where most FBC settlements occupied loess uplands.

The Sandomierz Upland (region 342.36 in Kondracki's 1994 taxonomy) is a north-eastern extension of the Holy Cross Mountains. It is a well-defined and rather flat area, rarely exceeding $300 \mathrm{~m}$ a.s.l., and bounded by river valleys: to the east by the upper Vistula, to the north by Kamienna, and to the west by Świślina. To the south, the upland is bound by the Wygiełzowskie Range and is drained by two Vistula tributaries, Opatówka and Koprzywianka (Kondracki 1994). The whole upland is covered with a 
thick layer of loess deposits accumulated during the Vistulian (Weichselian) glaciation. The eastern and northern borders of the upland have steep escarpment edges that abruptly descend to the bottoms of river valleys. The rest of the area is broken by numerous deep and narrow stream and river valleys. The major Vistula tributary, Opatówka, runs NW-SE through the region, but various small streams are oriented SW-NE, giving the local topography considerable variation (Fig. 1). To the south and southwest, clusters of the Holy Cross Mountains rise to around $600 \mathrm{~m}$ a.s.l., generating prominent landscape features.

Within the Stryczowice sub-region, FBC large settlements were located at the edge of river valleys, and some small and less permanent sites occupied loess uplands. In many cases, they were located where a Lengyel-Polgár settlement existed earlier (Burchard et al. 1991.100). Large settlements were established along small tributaries of the Kamionka River, which is exposed to the Sun, clustering around Stryczowice and Broniszowice, where the densest network of meandering stream valleys and richest rolling landscape features occur in the region $(B a-$ bel 1975.536). Apart from settlements, the outstanding characteristics of the FBC Eastern and SouthEastern Groups were the constructions of earthen long barrows. While in Pomerania, Greater Poland, Kuyavia and Lower Silesia, irregular boulders were used to enclose the mound, in the South-Eastern Group large blocks were replaced by smaller limestone stones or a timber palisade. Although lacking massive stones, the earthen long barrows erected in the Sandomierz Upland should also be interpreted as monumental tombs. Within the whole area, these earthen long barrows were usually situated near the highest elevations, include watershed splits (Babel 1975.535-536). The area is drained towards the north-east by the Kamionka River, which flows into the Kamienna, and then into the Vistula (see Fig. 1). Recently, Marek Florek (2011) aptly described all the mounds and barrows known in the region.

\section{Long barrows and their spatial perception}

To begin with, I will suggest that long barrows were often deliberately built in places so as to appear to create skylines viewed from neighbouring settlements. Viewed from settlements these barrows indeed were silhouetted, but no less important was the constitution of the visual network between barrows in the entire sub-region. I have discussed the visual appreciation of these monuments in detail

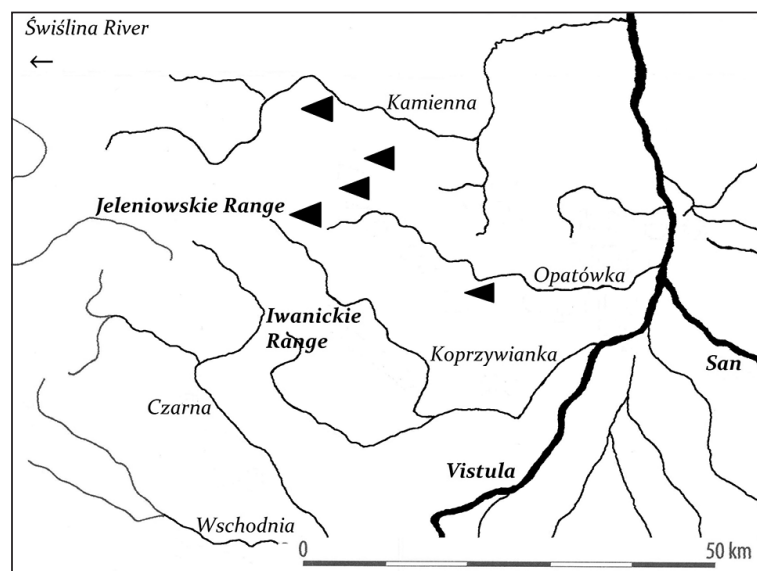

Fig. 1. Simplified map of the Sandomierz Upland.

elsewhere (Iwaniszewski 2006), but my aim here is to emphasise the reproduction of their privileged locations with respect to visual and astronomical involvements. My research indicates that the long barrows located in elevated positions have greater visual control of the overall environment than the settlements situated on the slopes descending to the riverine valleys. Furthermore, all long barrows investigated have visual predominance in almost all directions, while settlement areas tend to have more restricted visual relationships. This contrast in the visibility patterns suggests that the barrows' associated symbolism and meaning were probably extended over specific areas, linking monuments with exterior referents. The erection of long barrows at higher elevations may also be interpreted as the placement of the dead in closer proximity to the heavenly sphere. For these reasons, the location of the monuments and settlements in the landscape and their visual properties should be seen as reflecting patterns between two spatially separated, but also socially and ritually, parts of the same society. It seems evident that their visibility and intervisibility patterns and an overall spatial interplay were produced as a result of field clearing and deforestation.

The incorporation of these monuments into the landscape can be understood in the broader context of visual experiences. It seems evident they were unlikely to be visually perceived, unless we admit that the surrounding forest was cleared (see Tilley 2010. 47-49). Fortunately, there is much evidence for the burning of the natural vegetation from the Bronocice region in the south (Kruk et al. 1996.55-69; Kruk, Milisauskas 1999). Although the oldest traces of deforestation in Bronocice may derive from preFBC periods, the intensification of the slash-and-burn technique resulted in a substantial thinning of the forest cover during the Bronocice II-III, between 
3560 and 3100 BC (Kruk, Milisauskas 1999.120; Kruk et al. 1996.26, 68-69; Milisauskas et al. 2012. 81 ). The changes in the woodland cover in the Stryczowice sub-region have not been studied yet. The only, and indirect, evidence comes from Gawroniec Hill at Ćmielów (mid-4th millennium BC), located $15.5 \mathrm{~km}$ east-northeast of the Stryczowice long barrows, where, in the FBC context, archaeologists found mollusc shells of particular snail species (Krysiak 1952). The presence of these snails, which is indicative of the ecological conditions of habitats where they were found, suggests that in the Kamion$\mathrm{ka}$ and upper Kamienna areas some of the upland slopes and hilltops could also have already been partially deforested due to the expansion of croplands and pastures (Barga-Wiectawska, Jedynak 2014).

To sum up, these anthropogenic changes in the natural environment could have improved visibility conditions across the entire region. I do not want to say that the whole area was already totally and permanently deforested; what I am suggesting is that the fact that the monuments were erected near elevated prominences suggests they would become visible from similarly high and already deforested locations. So it is possible that grasslands mixed with agricultural plots and pockets of woodland dominated the upland loess landscape (see also Nowak 2009.449450). Observe the tree, water, wagon, and field motifs on a late Funnel Beaker vessel from the Bronocice phase II, dated to about 3637-3373 cal BC ( $M i$ lisauskas, Kruk 1982; Bakker et al. 1999.785-786), which seem to represent parcelled fields separated by trees (woodland?) (Fig. 2).

Diverse FBC groups inhabited the Stryczowice subregion for a longer time, not only significantly transforming the local landscape (deforestation produced

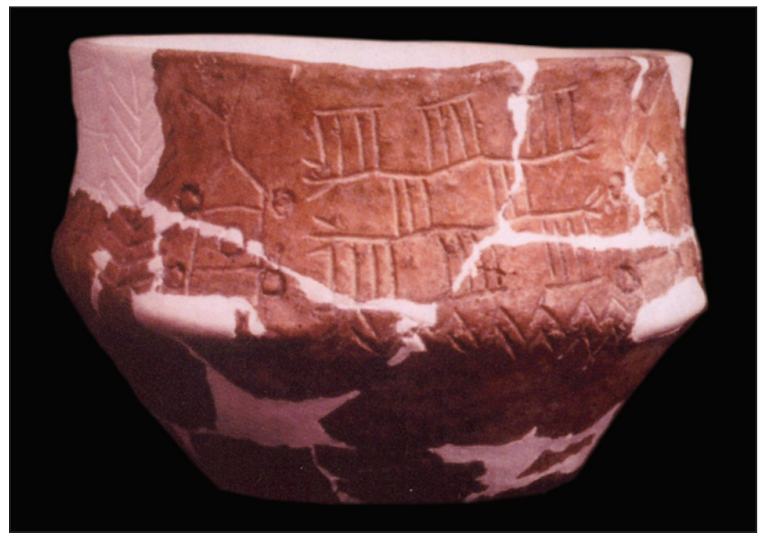

Fig. 2. A late FBC vessel from Bronocice showing the tree, water, wagon, and field motifs (after Kruk, Milisauskas 1999.P1. 4). by slash-and-burn and scratch plow agriculture and intensive grazing), but also dramatically changing their experience of the surrounding world, permitting them to create a visual relationship into a wider landscape experience. Naturally, it is hard to evaluate the overall extension of forest clearance, but examples from Bronocice suggest that an important part of the region, especially in the valleys, should have remained forest. Be that as it may, there can be little doubt that the growing importance of longdistance panoramas of landscapes required changes in traditional ways of perceiving the cosmos, both in terms of everyday habits and shared worldviews (see more in Tilley 2010.42-51). I am aware that the analysis of the visibility of the long barrows shows a tendency to emphasise them as primarily visual constructs, and stress visual perceptions of the landscape at the expense of other forms of landscape perception. This position appears to privilege knowledge gained through sight, which might be due to our western mode of seeing the landscape, and not one shared by FBC peoples (see Ingold 2000. 243-287; Cummings, Whittle 2004.8-9). Therefore, to avoid easy over-interpretation, I add to sight the notion of the feeling of the weather-world (Ingold 2010; 2011.126-135) which introduces a more multi-sensory experience of the surrounding world.

Having established that Middle Neolithic cereal agriculture and the maintenance of domesticated livestock could have caused more permanent deforestation of the region, I am now in a position to find out whether the monuments were oriented to the Sun's positions on the distant horizon. I am assuming that the elevated locations where the monuments were built allowed the horizon to be seen. As is known, archaeoastronomy maintains that orientations of structures have some meaning in relation to astronomical objects or events observed in the sky. This is not to say that different structures are set up in the landscape to represent patterns in the heavens for no other purpose. Rather it implies that their constructors laid them out to utilise the celestial realm as a way of a social discourse (e.g., to reinforce the elite's right to rule, to legitimise rituals performed on specific dates).

Within this context, we must attend more closely to the orientation patterns of long barrows. In general, all FBC long barrows, regardless of geographical location, appear to follow a more or less regular pattern of placing monuments on an E-W axis, with deviations to NE-SW and SE-NW (Iwaniszewski 2015). In Kuyavia, the overall majority of axes are situated 
within the angle of the annual movement of the Sun along the horizon, or the solar arc of the region (Iwaniszewski 1995). I assume that the axis of long barrows conveys a strong sense of a directed sightline determining movements toward and away from targeted landmarks and solar events. Therefore, astronomical sightlines may act as a means by which meanings and values projected onto distant landmarks are evoked at the monuments, with the monuments themselves associated with them (see below). In one a way or another, this pattern is indicative of a particular symbolic significance accorded to the $\mathrm{E}-\mathrm{W}$ axis and to astronomical phenomena that occurred along the horizon. If this last argument is valid, then FBC groups sought for suitable places that afford a sufficiently wide, but not necessarily panoramic, view. The sites of earthen long barrows appeared to meet those conditions and enabled the potential observers to see a horizon position of the Sun. Now, if observations made from these spots not only served to record of recurrent positions of the Sun, but also to schedule particular activities (such as planting or harvesting), they had to return to these places at regular intervals. The monuments physical presence in the landscape could have been used to assess and reassess the importance of the location from which astronomical observation was possible. The evidence for ritual practices found in the wider area of long barrows is evidence that these places were visited regularly. The orientation patterns of monuments suggest they could have acted as kinds of calendrical indicators for recurrent astronomical events, as well as for specific activities shared by whole communities.

\begin{tabular}{|lcc|}
\hline $\begin{array}{l}\text { Monument } \\
\begin{array}{l}\text { Stryczowice } \\
\text { long barrow 1 }\end{array}\end{array}$ & $\begin{array}{c}\text { Western alignment } \\
\text { (narrower end) }\end{array}$ & $\begin{array}{c}\text { Eastern alignment } \\
\text { (wider end) }\end{array}$ \\
\hline $\begin{array}{l}\text { Stryczowice } \\
\text { long barrow 2 }\end{array}$ & May 14-26//ung 11-14 22-Aug 2 & Jan 31-Feb 3/Nov 4-7 \\
\hline $\begin{array}{l}\text { Broniszowice } \\
\text { long barrow 1 }\end{array}$ & Apr 29/Aug 14 19/Nov 19-Dec 3 \\
\hline $\begin{array}{l}\text { Kunów, long barrow 1 } \\
\text { Malice Kościelne, }\end{array}$ & Apr 26/Aug 18 & Feb 11/Oct 31 \\
\hline $\begin{array}{l}\text { long barrow 1 } \\
\text { long barrow 2 }\end{array}$ & Feb 12/Oct 30 & Feb 19/Oct 23 \\
\hline $\begin{array}{l}\text { Malice Koś cielne, southern } \\
\text { side of long barrow 2 }\end{array}$ & Mar 14/Sep 30 & Apr 29/Aug 16 \\
\hline
\end{tabular}

Fig. 3. Alignments of earthen long barrows at the Sandomierz Upland. Dates arbitrarily computed for 3500 BC. Due to the lack of in situ measurements, the dates from Malice Kościelne should be taken as approximate ones (even as \pm 6 days).
Archaeoastronomical arguments are essential for this interpretation. All sites in the Stryczowice sub-region have been visited and examined (see Fig. 3). Since there may be some ambiguity as to the direction in which a given alignment might have been used, declinations were obtained in both directions. On the eastern Stryczowice eastern, the spread of declinations is between $-16^{\circ}$ and $-22^{\circ}$, corresponding to solar dates between February 3/November 7 and January $5 /$ December 3 . Westward orientations of both long barrows yield declinations between $15^{\circ}$ and $21^{\circ}$, corresponding to solar dates between May $1 / \mathrm{Au}-$ gust 14 and May 26/July 22. At Broniszowice, the axis of the long barrow extended eastward points to a declination close to $-14^{\circ}$, corresponding to solar dates of February 11/October 31. Its westward orientation corresponds to the days of April 29/August 14. The comparable solar dates collected at Kunów are February 19/October 23 for the barrow's eastern alignment and April 26/August 18 for the western one.

It is important to observe that orientation patterns of the FBC long barrows are not linked with turning points in the yearly solar cycle, namely, the solstices, and equinoxes. However, it is noteworthy that all orientations are located within the solar arc of particular sites, that is, within the angle of annual displacement of the Sun along the horizon, suggesting their constructors oriented them intentionally. It may imply that Funnel Beaker sky watchers were interested in specific dates marked by the rising and setting positions of the Sun rather than in astronomical events such as solstices or equinoxes. The meaning of the dates mentioned above will become evident when compared to the region's seasonal changes. So now I will attempt to find associations between the solar times determined by the axes of the long barrows and the annual distribution of climatic and ecological variables.

Today, the region has a dominant warm summer continental (Dfb) climate bordering on temperate oceanic climate $(\mathrm{Cfb})$. Notable precipitations occur in all seasons. The key months for seasonal climatic changes are February (the driest month), July (the warmest 
and also the wettest month), and January (the coldest month). However, the local climate may further be affected by the climatic conditions of the adjacent Holy Cross Mountains. After winter, minimum rainfall steadily increases from March to July. Soil moisture depends on rain, and any lack of rain in March-April and July may substantially reduce yields. The turn of April and May coincides with the onset of a warmer part of a year. Delayed frosts can occur as late as mid-May (Kowalski 1997.17). The ripening of cereals occurs between May and July, a time when rain is also required; a lack of rain in summer also reduces yields. In total, the duration of the growing period is about 200-210 days (see Fig. 4). It should be remembered that present-day climatic phenomena differ from those in the past. During the Atlantic climatic period (7460-3830 BC) the temperature in central Europe was $2^{\circ}$ higher than modern levels (e.g., Harmata 1995.33), so it is probable that delayed frosts were less frequent.

Overall, winds from the WSW and West bring most precipitations and increased cloud (Kowalski 1997). The wind rose from Sandomierz shows in the region the prevailing winds are from the West, WSW, and WNW (see Fig. 5).

To sum up, eastward and westward solar calendar dates roughly tend to cluster around the so-called mid-quarter days. As is known (e.g., McCluskey 1989), this term refers to dates falling midway between the dates of the solstices and equinoxes, i.e. at the beginning of February, on the turn of April and May, in mid-August and in November. Some scholars associate the quartering of the year with the traditional beginning of the four climatic seasons (Nilsson 1920.76; McCluskey 1989). However, in my opinion, it may well refer to the much earlier division of the year into cold and warm halves, with the starting dates around the beginning of November and of

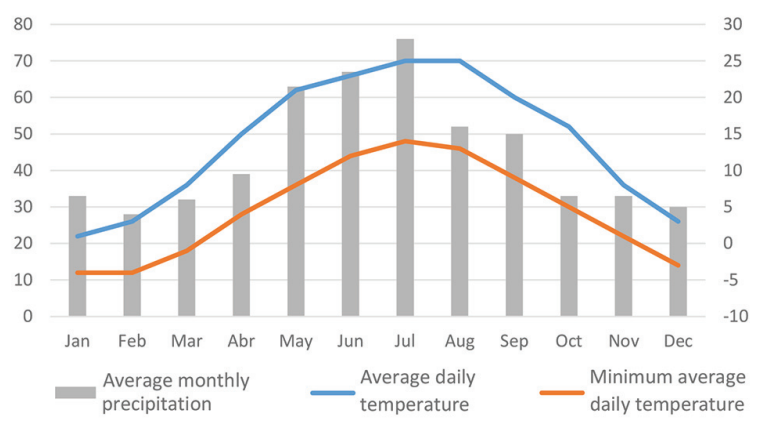

Fig. 4. Seasonal Cycles at Sandomierz. Source: me teoblue.com/pl/pogoda/prognoza/modelclimate/ sandomierz_polska_759603, acceded August, 2, 2016.

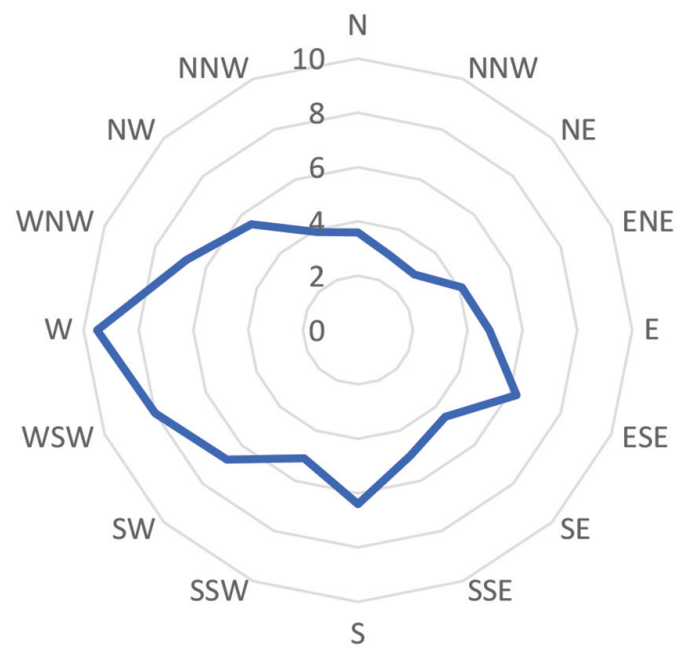

Fig. 5. Wind rose plot for Sandomierz. Source: me teoblue.com/pl/pogoda/prognoza/modelclimate/ sandomierz_polska_759603, acceded August 2, 2016.

May, respectively (Liugman 1938.445, 450-451). This concept finds additional support in the history of Indo-European languages. The earliest division of the year seems to have been based on the separation of two distinct seasons (either as 'wet' and 'dry' or as 'cold' and 'hot' seasons, Buck 1971.1011-1016). Nilsson (1920.45-85), who discusses the history of ancient European time-reckoning, also observes that the names of the seasons are borrowed from the names of the climatic phases.

The turn of April and May, as well as the turn of October and November, fall approximately at midpoints between the equinoxes and solstices. Thus, the orientations of Stryczowice, Broniszowice, and Kunów long barrows seem to be linked with turning points in the annual seasonal cycle (Fig. 6). The third turning point (at the turn of January and February) may eventually be related to the period of maximum cold, so its significance for the farming calendar is nil, since it is a resting time in agricultural activities. The fourth turning point, mid-August, may denote the end of harvest-time. The clustering around these dates may suggest they were the intended targets. of course, these associations are speculative, and the proposed link between the seasonal cycle and the third and fourth dates remains to be further explored.

I shall now recapitulate what archaeoastronomy adds to the overall image of long barrows' significance. The shape of earthen long barrows shows clear evidence of axiality. These monuments denote meaningful directions formulated in terms of alignments towards landscape and horizontal astronomi- 
cal targets at seasonally significant times. The meaning of the dates revealed by long barrow orientations is inferred from their correlation with important seasonal changes (such as rainfall, temperature, and vegetative cycles) and agricultural activities (planting, harvesting). In my opinion, the changing positions of the Sun along the horizon provide the temporal and spatial frame for activities performed at the monuments. It informed the potential participants of rituals about the context within which they acted. It shows that solar positions along the horizon cannot be interpreted as being observed by a detached Sun watcher interested in fixing the Sun's positions at the turning points of the annual solar cycle. Rather, solar positions should be viewed as being associated with other natural cyclical phenomena. If this is true, then we are dealing with new types of interpretation. The Sun might be considered as capable of communicating with humans, i.e. as being able to signal the change in the seasons and the need to start/end specific agricultural tasks. To sum up, locations of long barrows in high places, together with their solar alignments associated with seasonal changes seem to show new ways in which FBC peoples approached (and understood) their environs.

This idea leads me to the following proposal. The constructors of long barrows who observed the turning points in the annual agricultural cycle also discovered the recurrent character of particular weather patterns. Now, although long barrows were constructed and erected by living inhabitants, they were

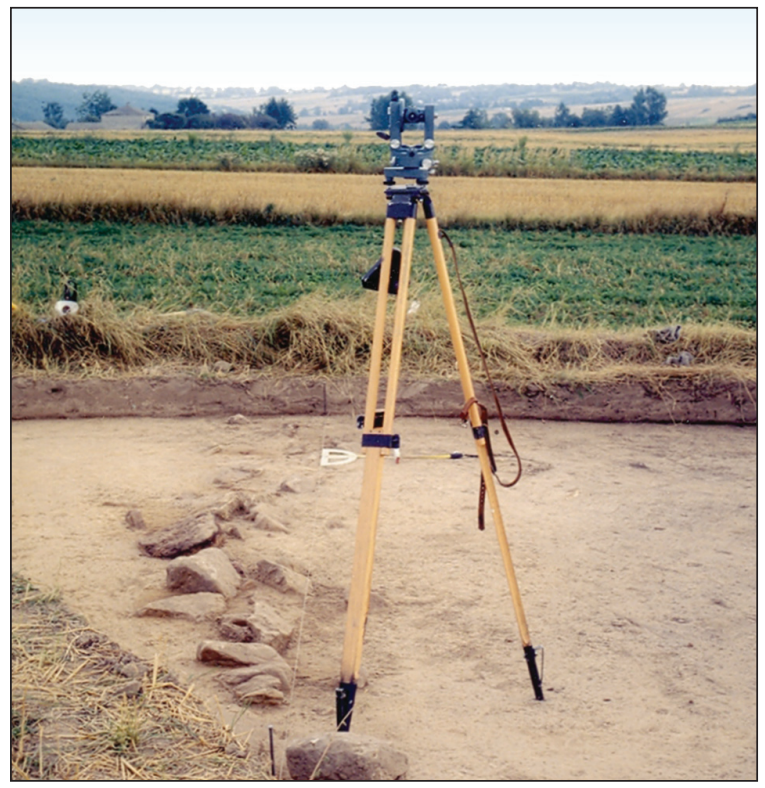

Fig. 6. Alignments of long barrow 2 at Stryczowice (photo by author). built to house the dead, mythical or real ancestors of the nearby villagers. To predict and thereby to control recurrent solar and weather, or astrometeorological, phenomena occurring at specific dates would have been the symbol and prerogative of those ancestors rather than of their living descendants. It might be that it was the ancestors buried under long barrows were who utilised the Sun to signal a change in the weather to humans. It might also be that these distant horizon features where the Sun was observed at meaningful dates provide indications about those ancestors abode. In the following, I will explore these possibilities.

Both proposals are in many ways speculative, but at least they fit the body of data we have at present.

The dead and the fertility of the soil: Neolithic beginnings of an agricultural metaphor in burial practices

As a particular kind of artefact, earthen long barrows have received numerous interpretations. However, these interpretations cannot be limited to socio-economic or ritual-mortuary issues. I suggest the spatial layout of long barrows not only permitted a new visual perception of the landscape, but also involved a different perception of the sky. Perceptions of the celestial vault within dense forest and cleared areas should have produced different experiences of the world, giving rise to new cosmological beliefs (Tilley 2010.50-51). Therefore, archaeoastronomy, together with walking around the landscape may add new evidence which allows the formation of new and more nuanced interpretations.

As has been suggested many times (Childe 1949; Fleming 1973; Kośko 1976; Hodder 1984; 1992; Midgley 1985; Sherratt 1990), the silhouette and outline of long barrows were regarded as imitations (in shape and arrangements) of monumental trapezoidal timber longhouses built by previous LBK (Linearbandkeramik) and Lengyel-Polgár groups. The arrangement of a series of long barrows at Stryczowice, Broniszowice, Garbacz-Skała, and Kunów suggests that a similar metaphor may have been used by Neolithic societies in this region. These 'villages for the dead' situated at the highest locations could have been easily seen from similar places in the upland, but remained invisible from the bottom of the river valleys or lower slopes descending into those valleys. It seems that long barrow locations were visually interconnected and involved in the same web of cosmological concepts. From this brief description, 
it is clear that their intervisibility and spatial interplay must be regarded as reflecting a new understanding of the landscape. In my opinion, these elements provide us with a potential guide to interpretation: uplands were associated with funerary monuments and dead ancestors, while lower slopes, lower elevations, and lowland river valleys were associated with living communities.

Furthermore, I also observed (Iwaniszewski 2006) that Funnel Beakers situated the barrows in the context of 'outdoor' activities performed outside settlements rather than within the sphere of daily household activities. Regarding the spatial pattern, long barrows were located in fields, grasslands, and forests, i.e. within areas of the routine, daily economic activities of Middle Neolithic societies. It is possible that long barrow locations were considered as desirable within a landscape in which primary 'outdoor' economic activities took place. Still, the association of essential economic activities such as gathering, farming or pasturing with enduring funeral monuments appears to be systematic regarding both spatial location and conception. Not only were they linked with the dead, with an ancestral presence in the landscape, and the possible reassessment of the rights over particular plots of land, but also represented a formalised and repeated pattern of social activities that could have been symbolically controlled by those ancestors. This ongoing transformation of the landscape could have provided both identities for the nearby population and symbols of authority imbued with religious meaning. Barrett makes a closely related point, observing that "as people move through their lands, not only do they learn about relationships between place and their ancestors but also learn about themselves and their particular rights and responsibilities in this land-based scheme of existence" (Barrett 1999. 193). My argument is that clearing the farmland of trees not only permitted the view that land ownership was ancestrally determined, but also that it derived its potency (or fertility) from powerful ancestors. In other words, what I am proposing here is the starting point of a process of associating a fertility cult with a cult of the dead that still is observed in Central European folk culture (e.g., Pisarzak 1978).

Although long barrows from the Stryczowice sub-region differ in many aspects (construction materials, location near water sources), they nevertheless match the FBC earthen long barrow general system. Their orientation, shape, size, and internal structure evince a formalised practice within well-defined spaces and follow a definite conceptual system.

In light of the above, it seems significant that the constructors of long barrows intentionally linked their orientations with turning points in the annual seasonal and farming cycles (and not with turning points in the solar year, such as solstices or equinoxes). Consequently, to predict or control those turning points by a dedicated ancestral monument would have been a symbol of the ancestors' power over the farming practices of their descendants.

\section{Malice Kościelne}

To test the hypothesis mentioned above, I examined two earthen long barrows at Malice Kościelne. Since I have not visited the site, my study relies on data provided by Barbara Bargieł and Marek Florek (2006a). The site occupies the southern bank of the Opatówka River, on the upper part of a slope falling towards the N-NE, about 34-35m above the present valley bottom. The site consists of the remains of two long barrows, and a nearby FBC settlement (about $200 \mathrm{~m}$ away). My calculations based on the maps and plans published by the authors and from Google Earth maps show that the barrows are roughly oriented towards the distant (over 18km) hills of the Iwanickie Range, which has summits above $300 \mathrm{~m}$ a.s.l. Declinations corrected for mean refraction vary between $-13^{\circ} 06^{\prime}$ and $-9^{\circ} 28^{\prime}$ (walls of Barrow 1 and the northern wall of Barrow 2), and correspond to sunset dates between Feb 12/Oct 30 and Feb 22/Oct 19) (Fig. 3). The Iwanickie Range may be used as a visual marker of the Koprzywianka River catchment area, which delimits the southern extension of the Sandomierz Upland. The Koprzywianka rises in the Jeleniowskie Range (below the Szczytniak summit, clearly visible from the Stryczowice Region) and flows into the Vistula in the city of Sandomierz.

Assuming that some alignments might be used in both directions, eastern declinations were also computed. On a nearby upland, there are a few small elevations, but they do not seem to be very impressive, so I cannot be sure of the intended direction. In general, these reverse alignments point to the distant and invisible valley of the Vistula, or to the place of the rising sun during the second half of April and August.

It is observed that the southern side of Barrow 2 is significantly skewed and displays alignments around the equinoxes. These are the only alignments that 
could have astronomical (i.e. equinoctial) meaning. Local topography shows that the longitudinal axes of both tombs are skewed from the mean axis of the slope on which they were built. The site is unusual in that the direct view to the South is entirely blocked by the nearby elevations (azimuths between $216^{\circ}$ and $183^{\circ}$ ), but does not affect vistas to the SouthWest and West. It seems therefore that through their alignments the tombs were deliberately placed to show visual links with a distant foresight where the Sun sets on specific days. Interestingly, this southwestern horizon cannot be observed from the nearby settlement area.

It is immediately evident that the Malice barrows are not aligned in the same way as those from the Stryczowice region (see Fig. 3). At Malice Kościelne, both long barrows are oriented along the SW-NE axis, while the Stryczowice ones prefer the SE-NW axis. Following Christopher Tilley (1984.122), this may be interpreted as signifying "the opposition or relations of non-identity" between two areas. Therefore, regarding the spatial pattern, it can be suggested that the Stryczowice and Malice Kościelne sites represent different social or political entities. However, in both cases, the long barrow orientations have clear connections with similar local climatic-meteorological cycles. Accepting that alignments were used in both directions, we find they are connected with almost the same turning points of the agricultural year. Therefore, although distinctly oriented, the Malice Kościelne long barrows appear to show the same concern with the solar dates as the ones in the Stryczowice sub-region.

In other words, in all the measured and analysed long barrows, the dates indicated by sunrise/sunset positions are close to the turning points of a seasonal calendar and may easily be associated with some ceremonial activities related to a fertility cult. The watershed of a given cycle (starting in October/November or in April/May) may be interpreted as signaling a liminal situation when one cycle ends and the other begins. The dead were naturally sent to the afterworld at different times, but privileged communication with them might have been achieved during these particular periods of the year. In this context, the above dates may also refer to liminal moments when the 'opening' and 'closing' of the natural world is observed, enabling the transition from the cold to warm or warm to cold halves of a year. These dates also enable open, direct and more efficient communication with the dead to be opened. In this way, the permanent link of long barrows with solar dates could have emphasised an idealised space/time structure shared by the members of a community and a particular association between the ancestors and the potential of cultivated fields.

\section{The realms of the land of the dead}

The wider ends of the excavated long barrows at Broniszowice, Stryczowice and Malice Kościelne, and a long barrow at Kunów, which has not been excavated, are on the eastern side. They are all situated near the highest parts of mounds. Although I consider the direction from the broader base towards the narrower end of a barrow to be the proper one (Iwaniszewski 1995.35), in the present paper both directions were assessed. The eastern horizon as observed from Stryczowice and Garbacz-Skała is connected to the distant and separate valley of the Opatówka River, a tributary of the Vistula. At Kunów and Broniszowice, however, direct views towards more distant horizon features are obstructed by the nearby hills. However, in all four cases, the long barrow alignments relate to distant horizon features located in the northwestern quadrant. I observed that the narrower and lower ends of long barrows tend to point to higher parts of distant horizons, while their higher and wider ' $\mathrm{fa}$ çades' seem to point much lower and nearer skylines. As the heads of the deceased were also oriented westward, it is possible that they were visually connected through the orientation of a long barrow to the distant and higher northwestern skyline.

Furthermore, Neolithic settlements here tend to be concentrated in the lower parts of the lands separated by adjacent smaller rivers or streams. They are located to the east and southeast of the Garbacz, Stryczowice, and Broniszowice long barrows. It seems, therefore, that in the entire micro-region, long barrows were built with entrances oriented downhill towards the nearby river valleys.

At Malice Kościelne, the FBC settlement is located to the NW, also on a slope descending to a river. The barrows are roughly oriented towards a distant and natural fore sight associated with the catchment area of a remote Vistula tributary. The eastward alignments point to the nearby Opatówka valley. Like all earthen long barrows built by Funnel Beakers, these monuments also display formalised and standardised ritual and spatial behaviour. The space in front of the long barrows seems to have had special ritual significance (Midgley 1985.64; Babel 2006) where people could have occasionally gathered. The creation of a ritual space for a local community so as 
to receive the rays of the rising Sun obviously contrasts with the position of the dead, who are oriented towards the direction where the Sun sets and from where winds, precipitation, storms, and thunder come. As stated above, the locations of long barrows invariably maintain a spatial separation from settlements. In this way, the dead gradually become more distanced from the living community to turn into ancestors or mythical figures relegated to an indefinite abode. In my opinion, the dead, ancestors or mythological subjects might finally be transformed into inhabitants of the world which they shared with the Sun and significant meteorological events. Although the dead were buried in long barrows, their 'real' abodes became the heavens containing the Sun and water. Thus the placement of those funerary monuments at elevated locations could have emphasised their proximity to the celestial sphere.

Having established that these long barrows were preferentially oriented towards higher features found on distant horizons, the reasons for such targets must be defined. In my opinion, the lack of easily observed waterways nearby on the eastern horizon is contrasted with the presence of a remote river valley on the northwestern horizon. The Stryczowice long barrows align with distant landmarks of the valley of the Świślina River. Not only is this a distant horizon, but it also relates to a distinct waterway. The same case is found at Malice, where the distant landmark (Iwanickie Range) is related to the Koprzywianka River. One reason for this pattern might be that long barrow orientations relate them to remote 'upper' cosmic waters, rather than with actual lower watercourses below. If this is true, then the monuments could have been metaphorically viewed as vehicles joining the Eastern and neighbouring world of living with the Northwestern, Western and Southwestern distant world of the dead. Since non-local horizon targets involve the presence of remote 'upper' waters, then it is probable that a symbolic association between the dead and agricultural lands is produced through the mediatory roles of solar events and water falling from the skies.

\section{South-eastern Funnel Beaker Culture and Tri- polye cultural affinities}

The Tripolye (Trypilia) culture occupied the territory between the Dnieper and the Carpathians next to the eastern limits of the southern-eastern FBC group (namely, the Lublin and Volhyn regions). This very rich painted-ware culture developed during the $5^{\text {th }}$, $4^{\text {th }}$ and $3^{\text {rd }}$ millennia BC. Wider relationships that existed between communities evident in Trypolyean cultural traits and their western neighbours (e.g., Balcer 1981; Kośko 1981; Jastrzębski 1985) resulted in the reception and adaptation of a great variety of Trypolyean cultural patterns by FBC groups. They ranged from technological and stylistic traits in pottery manufacturing to cosmological ideas associated with concepts of the afterlife and ancestors (Kośko 1981.123-162).

Close contacts between the Sandomierz Upland and Trypolean Culture (TC) are both reflected in imported materials and artefacts and imitations of them. Objects made of Volhynian flint or items imported from the Tripolye area were found at Ćmielów (3500-3200 BC; Balcer 2002.15, 90), Stryczowice (Matraszek 2001.287), Malice (Bargiet, Florek $2006 a$. 375, 380), and Pawłow (flat grave 3, Bargiet, Florek 2006b.386). Archaeologists have also identified several imported or imitated painted pottery forms and pigments at FBC sites of the Sandomierz Group: Kamień Łukawski (Kempisty 1968; Jastrzębski 1985), Stryczowice and Opatowice (Kadrow 2005.14-15; Kadrow 2009.140-142; Kośko et al. 1999) dated to $3640-2888 \mathrm{BC}$.

The growing number of Trypolyean finds within the Sandomierz area has led some researchers to propose (e.g., Kośko et al. 1999.288) that these FBC communities were 'trypolyezed' ('eneolithised'). Others suggest that contacts were in both directions (Videiko 1999.43-44). Still others suggest (Nowak 2014.193-194) the growing awareness of borderland society, which led to a very "peculiar, unique and autonomous space in relation to neighbouring areas."

To sum up, cultural exchange between FBC and TC groups occurred between 3640-2880 BC or during the Late Middle Neolithic period, when intensive agricultural activity resulted in the clearing of forest from uplands and slopes (Kruk, Milisauskas 1999. 312-316; Videiko 1999). It was during this time that FBC mortuary rituals were affected or influenced by south-eastern neighbours (Burchard et al. 1991. 99). Also, certain motifs found in the ornamentation of FBC pottery appear to be adapted from the Trypolean Culture (Videiko 1999.66).

\section{The upper world levels and motifs on the paint- ed pottery of Tripolye Culture}

So far, I have pointed out that long barrow orientations suggest that the ancestors' abode was localised 
in the upper regions of the universe. Within the Stryczowice sub-region, the northwestern part of the skyline was linked to the setting Sun and the moment the hot season arrived, especially the coming of spring storms, thunder and rain which typify the weather during the spring. The onset of the hot season may be identified through the alignments of long barrows, possibly conceptualised as 'houses of the dead'. I suggest that this relationship was reassessed through a series of ceremonies arranged to ensure good crops and the well-being of the ancestors who kept the fields fertile. The alignment came alive again shortly after the harvest. Ceremonies involving pouring grain from the recent harvest onto the monument to ensure a supply for the fields in the coming year could have been performed.

FBC groups evince a similar spatial-meteorologicalastronomical symbolism in Malice Kościelne. In February, they could have celebrated the transition from the dry to wet season, and when the Sun set over distant horizon fore sight in early November, they could have observed the arrival of the cold season and a significant decline in precipitation. Both calendar dates are liminal, since they indicate the transition from one season to another. In contrast with the Stryczowice region, where the calendar dates relate to the wet and hot season, at Malice Kościelne the solar calendar dates made manifest through alignments are associated with the dry, cold season.

The influence of TC noticed in the materials from the large FBC settlements in the Sandomierz sub-region of the southeastern $\mathrm{FBC}$ group allows me to ask whether any ideological or worldview patterns were imported from Tripolye Culture into the Sandomierz Upland.

My argument in this section will be that the location of the long barrows at the Stryczowice sub-region reflects a worldview which can be explained by specific depictions on Tripolye pottery. As is known, Boris A. Rybakov interpreted the motifs painted on Trypolyean cooking pottery in terms of a fertility cult. Furthermore, he concluded that these motifs represented the tripartite structure of the world ( $R y$ bakov 1965.37). Thus the upper band of wavy lines represented the 'upper' heavenly waters. Just below it, another band filled with spirals, solar and lunar symbols, and vertical streamer-type lines recalling falling rains rendered the 'upper' atmospheric-meteorological waters. The bottom band filled with vegetal, animal or human figures represented the level inhabited by people (see Fig. 7). It seems that the sky with its rain resources, together with the alternation of seasons and the life cycle, constituted central themes in the worldview of the Tripolyeans. $\mathrm{Cu}$ riously enough, there is no place for the dead in Rybakov's interpretation (compare Kośko 1981.159).

Today, many of these ascriptions of meanings may appear ambiguous. Scholars who examine these depictions usually focus on the ascription of meanings, and this idea is based on an interpretation of motifs as visual symbols or signs. For example, spiral ornaments are interpreted as visual images of serpents, celestial dragons, dragon-serpents and serpen-

Indo-European texts - the hymns of the Rigveda (dating approximately from the Second Millennium B.C.E.).

1. "Svah" is the upper sky with its supplies of water.

2. "Bhuvah" is the air space, with its stars, sun, and moon.

3. "Bhuh" is the earth, the soil.

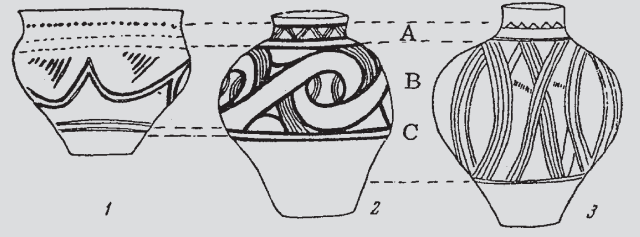

Fig. 14. Concept of the world in three levels.

A) the sky "svah"; B) the air "bhuvah; C) the earth "bhuh"; 1) Lenkovtsy; 2) Petreny; 3) Usatovo.

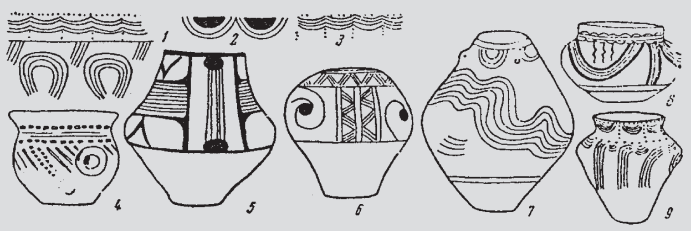

Fig. 19. The upper sky and heavenly water pouring down on the earth. 1) Kolomiia area; 2) Nezviski; 3) Khalep'e; 4) Luka-Vrublevetskaia; 5) Petreny; 6) Koscylowce; 7) Khalep'e; 8) Tiraspol'; 9) Khalep'e.

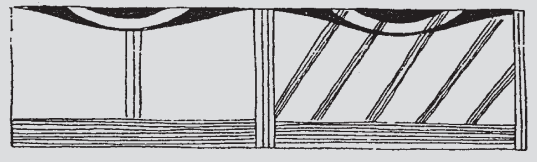

Fig. 20. Rain watering the earth: Schipenitz.

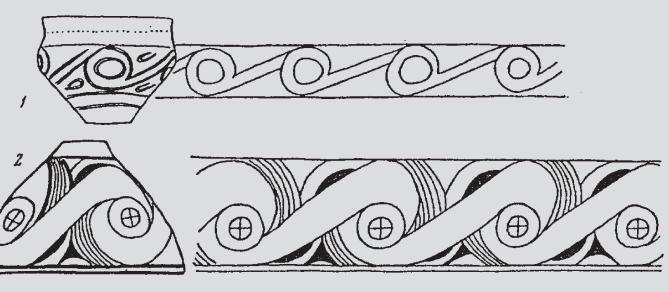

Fig. 21. The continuous course of the sun. 1) Lenkovtsy; 2) Petreny.

Fig. 7. Collage of Rybakov illustrations showing the vertical and tripartite structure of the Trypolyean cosmos (after Rybakov 1965). 
tine-like goddesses, or as solar signs (Palaguta 1999; 2009; Tsvek 1993.81-87).

The importance of water symbolism in funeral practices cannot be ruled out, since fragments of similar motifs have been found on pottery excavated at Broniszowice, Stryczowice, and Malice Kościelne. This fact enables us to explore other research possibilities.

Various scholars (e.g., Bradley 2000.60-63; Woźny 1996.50-55, Tab. 1, Map 1, 103-106; Adamczak 2013.183-180) have already noticed a correlation between the locations of long barrows and ritual deposits placed in water (springs, lakes, bogs, rivers). Watery associations between FBC settlements and long barrows have long been reported in other FBC groups. For example, in Kuyavia, Eastern Funnel Beakers often located their settlements and long barrows near water sources, deposited ritual items in water and used damp soils with snails and mussels to cover the dead in earthen long barrows ( $W O$ źny 1996.53-57, Tab. 1; Adamczak 2013.183-188). Similar votive bog deposits of the FBC have recently been suggested for the area of the South-Eastern Group (Libera, Zakościelna 2006). In the Sandomierz Upland, long barrows were located on raised loess hills, which are relatively dry areas. Unfortunately, the distribution of long barrows in connection with the locations of streams or springs has not been studied yet.

Now, according to Jerzy Bąbel (1979), Jacek Woźny (1996.55), and Kamil Adamczak (2013.184), the vessels used as ritual deposits seem to have shared a specific type of decoration. The most typical decorative motifs include wavy horizontal lines, or zigzags placed just below the rim, presumably representing water symbolism. Below them, sometimes motifs consisted of a central stalk and short lines in pairs placed at intervals and directed downwards, possibly representing trees or plants, seem to suggest a kind of composition containing a water and vegetative components (Woźny 1996. 103). According to Bąbel (1979) and Aleksander Kośko (1981.159-161) Funnel Beaker communities depicted celestial waters (in the form of horizontal lines), clouds (garlands) and falling waters (vertical rows of cuts). Note that, when connected with agriculture, such motifs may refer to the warmer half of the year, between March and July, when most rainfall occurs (Kowalski 1997. 17-18).

Assuming that the sky as conceptualised by Funnel Beakers was permeated with water and depicted in its pottery, one may ask whether the realm of the land of the dead was also related to water symbolism. My interpretation links the dead with celestial waters. It associates both the long barrows and the dead with the time when the warmer part of the year begins. The Earth is 'opened', so vegetation sprouts and the dead or the ancestors approach human settlements for food. Does it mean that it is the dead who pour water on the fields?

According to Rybakov (1965), the lower level of the sky was where celestial bodies pass across the heavens and rain waters were stored. It follows that the decorated pottery describes the relationship between the upper sky, the lower sky, and the land. Thus it represents two celestial layers rather than one. My interpretation links the dead with the waters above. Both proposals are in many ways speculative, but at least fit the body of data we have at present.

There is little evidence showing the Sun was imagined as an animate being, with agentive power. The status of ancestors seems to be different. Examples from the Northern Funnel Beaker Group indicate they could use ships to reach the heavens (Adamczak 2013.184), but no such associations are known in the area. Therefore, I assume that the ancestors buried under long barrows were considered as animate beings who used the Sun to signal changes in weather to humans.

\section{Conclusions}

The landscape, archaeoastronomical and symbolic analysis of long barrow locations in the Stryczowice micro-region reveal interesting patterns related to the worldview of its Neolithic inhabitants. Combined with the designs displayed on some $\mathrm{FBC}$ vessels, those examples show patterns of the worldview of FBC societies. Although FBC vessels seem to imitate the ornamentation of Tripolye pottery, which depict a three-level structure of the world, some substantial differences in both images of the universe existed. According to the present interpretation, the fertility of the fields was interwoven with an ancestor cult. Different elements in the sky were merged: the Sun, spring rains, rain-bringing winds, cold, dry winds, remote mountain landmarks, and ancestors. While the first two elements were possibly of Tripolyean origin, the development of long barrows in the region resulted in the placement of the dead in the western quadrant of the sky, where they became associated with waters. 
It can be argued that the dead were either incorporated into existing long barrows or were provided with monuments of their own to denote that the land - its productive-vegetative cycles - were owned or at least controlled by them. The dead were perhaps seen as having more permanence in the landscape than living communities and therefore had a longer-term claim to the land. On the other hand, the people were concerned with their own identity and defining themselves as separate from both the natural world and the physical location of the dead. The dead were approached and incorporated into systems of beliefs through the agricultural cycle itself. The structural organisational metaphor used to understand the world was based on the correlation made between astronomical and meteorological cycles.

This paper shows that archaeoastronomy can offer valuable insights into the study of the past. However, it also indicates that not all Neolithic monuments display align with turning points in the annual cycle. While such alignments may easily be dismissed by scholars whose research interest is lim- ited to seeking astronomically meaningful orientations, researchers with a keen interest in cultural phenomena may find this evidence strongly indicative of the intentions of long barrow builders and users. This type of research shows more affinities with the practice of archaeology than with archaeoastronomy itself (Bostwick 2006).

Archaeological research at Stryczowice was supported by the Polish Committee for Scientific Research (grant KBN Nr. T-186/267/P-DOT/00) and the State Archaeological Museum in Warsaw. The author thanks Barbara Matraszek, director of the Stryczowice archaeological project, for her generous invitation to conduct archaeoastronomical investigations and landscape observations. The author would like to thank Barbara Matraszek, Stawomir Sałacinski, Jerzy T. Babel and Bogdan Balcer for their helpful suggestions and comments on earlier drafts of this paper. This paper derives from the project 'Starry sky - an animated sky', initiated during my sabbatical leave in 2014. The author is also grateful to two anonymous reviewers for their helpful and valuable comments.

\section{References}

Adamczak K. 2013. Communities of the Funnel Beaker Culture During the Era of Erecting Monumental Tombs in the Territory of Poland: Rituals, Vessels and Social Divisions. In J. A. Bakker, S. B. C. Bloo and M. K. Dütting (eds.), From Funeral Monuments to Household Pottery: Current advances in Funnel Beaker Culture (TRB/TBK) research. British Archaeological Reports IS 2474. Archaeopress. Oxford: 177-193.

Balcer B. 1981. Związki między kulturą pucharów lejkowatych (KPL) a kultura trypolska (KT) na podstawie materiałów krzemiennych. In T. Wiślański (ed.), Kultura pucharów lejkowatych w Polsce. Polska Akademia Nauk. Poznań: 81-91.

2002. Ćmielów, Krzemionki, Świeciechów. Związi osady neolitycznej z kopalniami krzemienia. Instytut Archeologii i Etnologii Polskiej Akademii Nauk. Warszawa.

Bakker J. A., Kruk J., Lanting A. E. and Milisauskas S. 1999. The earliest evidence of wheeled vehicles in Europe and the Near East. Antiquity 73: 778-790.

Barga-Więcławska J. A., Jedynak A. 2014. The Contribution of Mollusc Shells in the Reconstruction of the Natural Environment and the Human Economy of the Northern Part of the Sandomierz Upland in the Third Millennium BC The Case Study of Site 63 in Krzczonowice (South-Eastern Poland). Sprawozdania Archeologiczne 66: 285-314.

Bargieł B., Florek M. 2006a. Cmentarzysko ludności kultury pucharów lejkowatych na stanowisku $1 \mathrm{w}$ Malicach Kościelnych, pow. Opatów. In J. Libera, K. Tunia (eds.), Idea megalityczna $w$ obrzadku pogrzebowym kultury pucharów lejkowatych. Instytut Archeologii Polskiej Akademii Nauk, Oddział w Krakowie and Instytut Archeologii Uniwersytetu im. Marii Curie-Skłodowskiej. Lublin, Kraków: 361-384.

2006b. Cmentarzysko w Pawłowie, pow. Sandomierz na tle innych podobnych stanowisk kultury pucharów lejkowatych. In J. Libera, K. Tunia (eds.), Idea megalityczna w obrządku pogrzebowym kultury pucharów lejkowatych. Instytut Archeologii Polskiej Akademii Nauk, Oddział w Krakowie and Instytut Archeologii Uniwersytetu im. Marii Curie-Skłodowskiej. Lublin, Kraków: 385-400.

Barrett J. C. 1999 The Mythical Landscapes of the British Iron Age. In W. Ashmore, A. B. Knapp (eds.), Archaeologies of Landscape, Contemporary Perspectives. Blackwell. Malden: 253-265. 
Bąbel J. 1975. Badania powierzchniowe dorzecza rzeki Kamionki, w pow. Opatowskim (Surface investigations in the Basin of the Kamionka River, Opatów District). Wiadomości Archeologiczne 40(4): 531-580.

1979. W poszukiwaniu obrazu kosmosu (In search of the image of Cosmos). Z Otchłani wieków 45(1): 28-33.

2006. Próba rekonstrukcji grobowca megalitycznego ze stanowiska V w Broniszowicach, pow. Ostrowiec Ŝwiętokrzyski. In J. Libera, K. Tunia (eds.), Idea megalityczna w obrządku pogrzebowym kultury pucharów lejkowatych. Instytut Archeologii Polskiej Akademii Nauk, Oddział w Krakowie and Instytut Archeologii Uniwersytetu im. Marii Curie-Skłodowskiej. Lublin, Kraków: 271-288.

Bostwick T. W. 2006. Archaeoastronomy at the gates of orthodoxy: introduction to the Oxford VII International Conference on Archaeoastronomy. In T. W. Bostwick, B. Bates (eds.), Viewing the Sky Through Past and Present Cultures. Selected Papers from the Oxford VII International Conference on Archaeoastronomy. Pueblo Grande Museum Anthropological Papers, 15. City of Phoenix Parks and Recreation Department. Phoenix: 1-13.

Buck C. D. 1971. A Dictionary of selected Synonims in the Principal Indo-European languages. A Contribution oto te History of Ideas. The University of Chicago Press. Chicago, London.

Burchard B., Jastrzębski S. and Kruk J. 1991. Some questions at Funnel Beaker culture south-eastern group. An outline. In D. Jankowska (ed.), Die Trichterbeckerkultur. Neue Forschungen und Hypothesen. Wydawnictwa Uniwersytetu im. Adama Mickiewicza. Band 2. Poznań: 95101.

Childe G. V. 1949. The origin of Neolithic culture in northern Europe. Antiquity 23: 129-135.

Cummings V., Whittle A. 2004. Places of special virtue: megaliths in the Neolithic landscapes of Wales. Oxbow Books. Oxford.

Fleming A. 1973. Tombs for the living. Man 8: 177-193.

Florek M. 2011. Kopce i cmentarzyska kurhanowe na Wyżynie Sandomierskiej. In H. Kowalewska-Marszałek, P. Włodarczak (eds.), Kurhany $i$ obrzadek pogrzebowy $w$ IV-II tysiacleciu p.n.e. Instytut Archeologii i Etnologii Polskiej Akademii Nauk \& Instytut Archeologii Uniwersytetu Warszawskiego. Kraków-Warszawa: 235-254.

Harmata K. 1995. A Late Glacial and Early Holocene Profile from Jasło and a Recapitulation of the Studies on the Vegetational History of the Jasło-Sanok Depression in the Last 13000 Years. Acta Palaeobotanica 35(1): 15-45.
Hodder I. 1984. Burials, houses, women and men in the European Neolithic. In D. Miller, C. Tilley (eds.), Ideology, Power and Prehistory. Cambridge University Press. Cambridge: 51-86.

1992. Symbolism, meaning and context. In I. Hodder (ed.), Theory and Practice in Archaeology Material Cultures. Routledge. London: 11-23.

Ingold T. 2000. The Perception of the Environment. Essays in Livehood, Dwelling and Skill. Routledge. London.

2010. Footprints through the weather-world: walking, breathing, knowing. Journal of the Royal Anthropological Institute (Special Issue): 121-139.

2011. Landscape or Weather-World. In T. Ingold, Being Alive. Essays on Movement, Knowledge and Description. Routledge. London: 126-135.

Iwaniszewski S. 1995. The Funnel Beaker Culture (TRB) Long Barrows from the Kujawy District in Central Poland. First results of Archaeoastronomical Investigations. In E. Pásztor (ed.), Archaeoastronomy from Scandinavia to Sardinia: Current problems and future of archaeoastronomy 2. Budapest: 33-37.

2006. Megalityczny obrządek pogrzebowy i neolityczny krajobraz w mikroregionie stryczowickim na Wyżynie Sandomiersko-0patowskiej. In J. Libera, K. Tunia (eds.), Idea megalityczna $w$ obrządku pogrzebowym kultury pucharów lejkowatych. Instytut Archeologii Polskiej Akademii Nauk, Oddział w Krakowie and Instytut Archeologii Uniwersytetu im. Marii Curie-Skłodowskiej. Lublin, Kraków: 259-269.

2015. TRB Megalithic Tombs and Long Barrows in Central Europe. In C. L. N. Ruggles (ed.), Handbook of Archaeoastronomy and Ethnoastronomy. Springer Science + Business Media. New York: 1299-1305.

Jastrzębski S. 1985. Imports of the Trypole Culture pottery in the south-eastern Group of the Funnel Beaker Culture. In A. Kokowski (ed.), Momoires Archéologiques. Uniwersytet im. Marii Curie-Skłodowskiej. Lublin: 71-92

Kadrow S. 2005. Związki kultury trypolskiej z kulturami Środkowej i Południowo-Wschodniej Europy. In A. Garbacz, M. Kuraś (eds.), Kultura trypolska. Wybrane problemy. Muzeum Regionalne w Stalowej Woli. Stalowa Wola: 7-31.

2009. Uwagi o grupie południowo-wschodniej kultury pucharów lejkowatych (Some remarks on the southeastern group of the Funnel Beaker Culture). In H. Taras, A. Zakościelna (eds.), Hereditas praeteriti: Additamenta archaeologica et historica dedicata Ioanni Gurba Octogesimo Anno Nascendi. Instytut Archeolo- 
gii Uniwersytetu im. Marii Curie-Skłodowskiej w Lublinie. Lublin: 137-144.

Kempisty E. 1968. Odkrycie ceramiki kultury trypolskiej na zachód od Wisty. (Discovery of the pottery of the Tripolye Culture to the west of the Vistula river). Wiadomości Archeologiczne 33(3-4): 377-480.

Kondracki J. 1994. Geografia Polski: Mezoregiony fizycznogeograficzne. Państwowe Wydawnictwo Naukowe. Warszawa.

Kośko A. 1976. Przyczynek do badań nad genezą i rozwojem kujawskiej enklawy tzw. "grobowców bezkomorowych". Archeologia Polski 21: 402-406.

1981. Udziat potudniowo-wschodnioeuropejskich wzorców kulturowych w rozwoju niżowych społeczeństw kultury pucharów lejkowatych. (The share of the South-East European cultural models in the development of lowland communities of Funnel Beaker Culture. The Matwy Goup). Wydawnictwa Naukowe Uniwersytetu im. Adama Mickiewicza. Poznań.

Kośko A., Langer J. J. and Szmyt M. 1999. Painted Pottery as a Symptom of Tripolye "Influence" in the Circle of Neolithic Vistula Cultures. Baltic-Pontic Studies 9: 282-288.

Kowalski J. 1997. Środowisko geograficzne. In Ostrowiec Świętokrzyski. Monografia historyczna miasta. Wydawnictwo Muzeum Historyczno-Archeologicznego w Ostrowcu Świętokrzyskim. Ostrowiec Świętokrzyski: 12-23.

Kruk J., Milisauskas S. 1999. Rozkwit i upadek społeczeństw rolniczych neolitu (The Rise and Fall of Neolithic Societies). Instytut Archeologii i Etnologii Polskiej Akademii Nauk. Kraków.

Kruk J., Milisauskas S., Alexandrowicz S. W. and Śnieszko Z. 1996. Osadnictwo $i$ zmiany środowiska naturalnego wyżyn lessowych. Studium archeologiczne i paleogeograficzne nad neolitem w dorzeczu Nidzicy. Instytut Archeologii i Etnologii Polskiej Akademii Nauk, Kraków.

Krysiak K. 1952 Szczątki zwierzęce z osady neolitycznej w Ćmielowie. Wiadomości Archeologiczne 18(3-4): 251290.

Libera J., Zakościelna A. 2006. Inwentarze krzemienne z grobów grupy południowo-wschodniej kultury pucharów lejkowaty. In J. Libera, K. Tunia (eds.), Idea megalityczna w obrzadku pogrzebowym kultury pucharów lejkowatych. Instytut Archeologii Polskiej Akademii Nauk, Oddział w Krakowie and Instytut Archeologii Uniwersytetu im. Marii Curie-Skłodowskiej. Lublin, Kraków: 135-169.

Liugman W. 1938. Traditionswanderungen Euphrat-Rhein. Studien zur Geschichte der Volksbräuche. FF Communications 119. Suomalainen Tiedeakatemia, Helsinki.
Matraszek B. 2001. Sprawozdanie z trzech sezonów badań na wielokulturowym stanowisku w Stryczowicach, gm.Waśniów, woj. świętokrzyskie. Sprawozdania Archeologiczne 53: 273-287.

McCluskey S. C. 1989. The mid-quarter days and the historical survival of British folk astronomy. Archaeoastronomy (JHA): S1-S19.

Midgley M. 1985. The origin and function of the earthen long barrows of Northern Europe. British Archaeological Reports IS 259. Archaeopress. Oxford.

1992. TRB Culture. The First Farmers of the North European Plain. Edinburgh University Press. Edinburgh.

2008. The Megaliths of Northern Europe. Routledge. London, New York.

Milisauskas S., Kruk J. 1982. Die Wagendarstellung auf einem Trichterbecher aus Bronocice in Polen. Archäologisches Korrespondenzblatt 12(2): 141-144.

Milisauskas S., Kruk J., Ford, R. and Lityńska-Zając M. 2012. Neolithic Plant Exploitation at Bronocice. Sprawozdania Archeologiczne 64: 77-112.

Nilsson M. P.1920. Primitive time-reckoning. Skrifter utgivna av humanistiska vetenskapssamfundet i Lund. C. W. K. Gleerup. Lund.

Nowak M. 2009. Drugi etap neolityzacji ziem polskich. Instytut Archeologii Uniwersytetu Jagiellońskiego. Kraków.

2014. Identity of FBC Societies in the Upper Vistula Basin. In M. Furholt, M. Hinz, D. Mischka, G. Noble, and D. Olausson (eds.), Landscapes, Histories and Societies in the Northern European Neolithic. Frühe Monumentalität und soziale Differenzierung, Band 4. Verlag Dr. Rudolf Habelt GmbH. Bonn: 185-195.

Palaguta I. V. 1999. Problemy izucheniya spiral'nykh ornamentov tripol'skoy keramiki. SP2. Kishinyev: 148-159.

2009. Yavleniye obratimosti i osnovnyye napravleniya razvitiya kompozitsiy ornamentov tripol'sko-kukutenskoy keramiki. In Materiyaly 9-go - 11-go zasedaniy nauchno-metodicheskogo seminara "Twerskaya zemlya $i$ sopredel'nyye territorii $v$ drevnosti". Tverskoy arkheologicheskiy sbornik, 7. Izdatel'stvo Triada. Tver: 411-418.

Pisarzak M. 1978. Obrzędowość wiosenna w dawnych wiekach. W związku z recepcją "święconego" w Polsce. Lud 62: $53-74$.

Rybakov B. A. 1965. Kosmogoniya i miphologiya zemledeltsev eneolita/Cosmogony and mythology of the agriculturalists of the Eneolithic (parts 1-2). Sovetskaya arkhe- 
ologiya 1: 24-47; Sovetskaya arkheologiya 2: 13-32. Translated into English in Soviet Anthropology and Archeology IV(2): 16-36; Soviet Anthropology and Archeology IV(3): 33-52.

Sherratt A. 1990. The genesis of megaliths. World Archaeology 22: 147-167.

Tilley C. 1984. Ideology and the legitimation of power in the Middle Neolithic of Southern Sweden. In D. Miller, C. Tilley (eds.), Ideology, power and prehistory. New directions in archaeology. Cambridge University Press. Cambridge: 111-146.
2010. Interpreting Landscape. Geologies, Topographies, Identities. (Explorations in Landscape Phenomenology, 3). Left Coast Press, Inc. Walnut Creek.

Tsvek 0. V. 1993. Religiyni uyavlennya naselennya Tripilya. Arkheologiya 3: 71-91.

Videiko M. Y.1999. Tripolye and the Cultures of Central Europe: Facts and the Character of Interactions: 42002750 BC. Baltic-Pontic Studies 9: 13-68.

Woźny J. 1996. Symbolika wody w pradziejach Polski. Wydawnictwo Uczelniane Wyższej Szkoły Pedagogicznej. Bydgoszcz. 
